Ann. Biol. anim. Bioch. Biophys., 1978, 18 (2A), 219-227.

\title{
A study of the roles of the mother and the embryo in rat egg implantation using blastocyst substitution
}

\author{
par Annie REBER
}

Laboratoire de Physiologie animale, Université de Rouen, 10, boulevard de Broglie, 76130 Mont Saint Aignon, France

\begin{abstract}
Summary. The roles played by the mother and the embryo in egg distribution along the uterine horns and in decidualization were studied in rats using resin artificial eggs as blastocyst simulators. Artificial eggs were introduced at the top of the uterine lumen in cyclic females, between days 2 and 6 post-coitum in pseudopregnant females, or in the sterile horns of pregnant ones. The artificial eggs were located $24 \mathrm{hrs}$ after they were introduced into cyclic rats and on day 7 in the other subjects. Histological study was effected when swellings were present on the uterine horn. The artificial eggs were usually expulsed when introduced before day 4 , at the time the blastocysts normally reach the control uterine horns. After that day, the uterus retained some of the artificial eggs, which were irregularly distributed along the horns and induced smaller deciduomata than blastocysts do. The decidua cell reaction was still initiated by stimulation of artificial egg on day 6 postcoitum. The blastocysts thus seemed to play an active part in the processes of distribution and implantation.
\end{abstract}

\section{Introduction.}

There is a lack of precise data in the literature concerning the roles of the mother and the embryo in egg distribution along the uterine horns and in decidualization.

Sea urchin ova, directly injected into the uterine lumen of the experimental rabbit, are distributed in the uterus by myometrial contractions during estrus until day 5 of pseudopregnancy, after which time the contractions decrease (Markee, 1944). Microspherical beads of glass or acrylic polymer, injected at the top of the mouse uterus on day 3 or 4 of pseudopregnancy, are usually observed clumped together at the top or the bottom of the horn on day 4 or 5 (McLaren, 1968). This dœs not apply to blastocyst distribution in rats which is more regular (Reber, 1972).

Decidualization can be induced in pseudopregnant rats, by intraluminal injection of histamine or oil or by endometrial scratching on day 5 (Shelesnyak, 1957). It can also be induced during day 4 post-coitum because rat uterus becomes sensitive to these stimuli on day 4 , reaches a maximal sensitivity level on day 5 , then becomes insensitive on day 6 post-coitum (De Feo, 1967). When introduced on day 4 of pregnancy, paraffin or glass beads also cause a decidual reaction in the sterile horn of unilaterally pregnant rats, while mouse and sea urchin ova do not (Alden and Smith, 
1959). However, glass beads are unable to induce decidual response in pseudopregnant mice ; thus physical distention of the uterine lumen by the blastocyst in mice dœs not induce per se decidual response (McLaren, 1968). The decidua initiated by artificial eggs are smaller in size that those induced by the blastocysts (Alden and Smith, 1959), and they increase more slowly (Finn and Porter, 1975).

Our present study attempts to present some data on the role of the uterus and the possible role of the embryo in egg distribution and decidualization in the rat uterus. We substituted inert particles for blastocysts in one of the two uterine horns of pregnant females and compared the spacing of the inert particles in that horn to blastocyst distribution in the horns of pregnant control rats. We also compared decidualization in horns with inert particles or with blastocysts. To see if the presence of fertilized ova in the control horn affected spacing or decidualization in the other, we compared pregnant females with blastocysts in one horn and inert particles in the other to pseudopregnant animals without blastocysts but with particles in one horn. Some maternal effect subsequent to coitum is discussed by comparing pregnant and cyclic females.

\section{Material and methods.}

Virgin female Wistar rats 2.5 to 3 months old, weighing 180 to $220 \mathrm{~g}$, and bred in the laboratory under natural lighting conditions were fed pellets and given water to drink ad libitum. The animals were caged for one night with males and successful mating was confirmed the following morning (designated as day 1 of pregnancy) by the presence of spermatozoa in the vaginal smear. When the animals were caged with vasectomized males, the presence of a vaginal plug designated day 1 of pseudopregnancy. The animals were considered as pseudo-pregnant if they did not return to estrus on day 4 post-coitum. The rats were anesthetized with ether or Nembutal for surgery.

Three groups of females were injected at the top of the uterine horns in the lumen with a saline solution ( 9 p. $1000 \mathrm{NaCl}$ ) containing artificial eggs of Sephadex resin. The diameter of the ova (200-300 $\mathrm{m} \mu)$ was comparable to that of the blastocysis

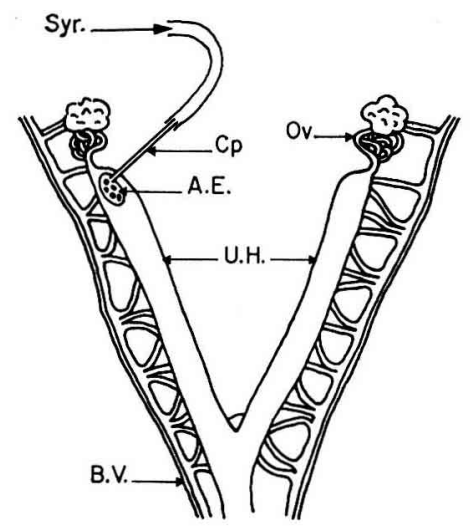

FIG. 1. - Injection of artificial eggs in the apical end of the uterine horn. $C_{P}$ : capillary glass; OV : oviduct ; Syr.: syringe ; UH : uterine horn ; A. E. : artificial eggs ; B. V. : Blood vessels. 
(280 mu) (Witschi, 1962). After potassium ferrocyanide and ferrous sulphate staining for several hours, they were washed and recovered in a capillary glass containing a saline solution for injection.

Group 1 : At a precise stage of the estrous cycle defermined by vaginal smear, 24 cyclic females were injected with 5 artificial eggs in both uterine horns. 24 hrs later the rats were killed and each horn opened longitudinally along the antimesometrial pole to locate these eggs.

Group 2 : In 91 pregnant rats, one of the oviducts was ligated near the uterofubal junction during the first two days of pregnancy to prevent the eggs from reaching the corresponding uterine horn. This horn was injected with 5 artificial eggs on day 2, 3 or 4 of pregnancy or with 1 to 15 eggs on day 6 . The site of the eggs was determined in the afternoon of day 7.

Group $3: 39$ pseudopregnant rats were injected with 5 artificial eggs in one of the uterine horns on day 2, 3, 4 or 6 post-coitum. Their presence was detected on day 7.

In uterine horns with swellings, artificial ova were located through the transparent uterine wall. The uterus was totally removed, fixed and embedded in paraffin wax. The cross-sections were then stained with hemalun-eosin for histological study.

The number of swellings on the normal pregnant horn and the number of corpora lutea in the ovaries of both pregnant and pseudopregnant rats were determined. To detect a possible significant difference between artificial egg and blastocyst distribution, we compared the mean position (percentage of distance travelled from the uterotubal junction) of artificial eggs to that of blastocysts. In a preliminary study, we had shown that injection of $0.02 \mathrm{ml}$ of the 9 p. $1000 \mathrm{NaCl}$ solution, used for introducing the artificial eggs, could not initiate a deciduomata.

\section{TABLE 1}

Transfer and defection of artificial eggs in cyclic female rats

Duration of estrus cycle, stage at transfer and examination of artificial eggs are noted in columns 1 , 2 and 3. Number of females examined and those losing or keeping artificial eggs are noted in columns 4, 5 and 6. Mean number of artificial eggs recovered is given in italics (column 6).

\begin{tabular}{|c|c|c|c|c|c|}
\hline \multicolumn{3}{|c|}{ Cycles } & \multicolumn{3}{|c|}{ Number of females } \\
\hline \multirow{2}{*}{$\begin{array}{c}\text { Duration } \\
\text { of } \\
\text { estrus cycle }\end{array}$} & \multicolumn{2}{|c|}{ Stage of estrus cycle } & \multirow{2}{*}{ observed } & \multirow{2}{*}{$\begin{array}{l}\text { without } \\
\text { artificial eggs } \\
\text { at examination }\end{array}$} & \multirow{2}{*}{$\begin{array}{l}\text { with } \\
\text { artificial eggs } \\
\text { at examination }\end{array}$} \\
\hline & at transfer & at examination & & & \\
\hline $\begin{array}{l}5 \\
4 \\
5 \\
5 \\
5 \\
4 \\
5 \\
4 \\
4 \\
6\end{array}$ & $\begin{array}{l}\text { Prostrus } \\
\text { Proestrus } \\
\text { Pro.-Est. } \\
\text { Estrus } \\
\text { Diestrus } 1 \\
\text { Diestrus } 1 \\
\text { Diestrus } 2 \\
\text { Diestrus } 2 \\
\text { Diestrus } 2 \\
\text { Diestrus } 2\end{array}$ & $\begin{array}{l}\text { Estrus } \\
\text { Estrus } \\
\text { Diestrus } 1 \\
\text { Diestrus } 1 \\
\text { Diestrus } 2 \\
\text { Diestrus } 2 \\
\text { Prcestrus } \\
\text { Prcestrus } \\
\text { Prcestrus } \\
\text { Prcestrus }\end{array}$ & $\begin{array}{l}5 \\
1 \\
1 \\
6 \\
3 \\
1 \\
4 \\
1 \\
1 \\
1\end{array}$ & $\begin{array}{l}3 \\
1 \\
1 \\
4 \\
3 \\
1 \\
0 \\
0 \\
0 \\
0\end{array}$ & $\begin{array}{l}4(3.5) \\
1(3) \\
1(2) \\
1(4)\end{array}$ \\
\hline
\end{tabular}




\section{Results.}

When artificial eggs were transferred between prostrus and diestrus 1 , none were found $24 \mathrm{hrs}$ later in 13 virgin rats out of 17 . The remaining 4 females kept only 22 of the 40 transferred ova. When the eggs were transferred at diestrus 2, all the females had artificial eggs ( 23 out of the 70 transferred) 24 hrs later. The results are summarized in table 1.

No pregnant rat given 5 artificial eggs on day 2 post-coitum had retained any when observed on day 7 post-coitum (table 2); one of them presented a swelling. When transfer was done on day 3 , one female retained one artificial egg and some presented swellings on the recipient horn (Plate I, fig. 1). When the artificial eggs were transferred on day 4 , some rats (7 out of 11 ) retained a great number of them and

\section{TABLE 2}

Number of artificial eggs and swellings found on day 7 post-coitum

Number of pregnant and pseudopregnant females with artificial eggs, with swellings at examination on day 7 in columns 4 and 5. Mean number of artificial eggs and swellings at examination in columns 6 and 7 . For mean number of artificial ova and swellings, only females with artificial ova or with swellings are considered.

\begin{tabular}{|c|c|c|c|c|c|c|}
\hline & \multirow{2}{*}{$\begin{array}{l}\text { Date of transfer } \\
\text { in days post-coifum }\end{array}$} & \multicolumn{3}{|c|}{ Number of femoles } & \multicolumn{2}{|c|}{ Mean number of } \\
\hline & & observed & $\begin{array}{l}\text { with } \\
\text { artificial ora }\end{array}$ & $\begin{array}{l}\text { with } \\
\text { swellings }\end{array}$ & $\begin{array}{l}\text { artificial } \\
\text { ova }\end{array}$ & swellings \\
\hline $\begin{array}{l}\text { Pregnant } \\
\text { recipients }\end{array}$ & $\begin{array}{l}\text { 2nd } \\
\text { 3rd } \\
4 \text { th } \\
6 \text { th }\end{array}$ & $\begin{array}{r}8 \\
20 \\
11 \\
21\end{array}$ & $\begin{array}{r}0 \\
1 \\
7 \\
20\end{array}$ & $\begin{array}{r}1 \\
6 \\
5 \\
12\end{array}$ & $\begin{array}{l}0 \\
1 \\
2.2 \\
4.1\end{array}$ & $\begin{array}{l}1 \\
3.4 \\
3.6 \\
3.3\end{array}$ \\
\hline $\begin{array}{l}\text { Pseudo-pregnant } \\
\text { recipients }\end{array}$ & $\begin{array}{l}\text { 2nd } \\
\text { 3rd } \\
4 \text { th } \\
\text { 6th }\end{array}$ & $\begin{array}{r}5 \\
10 \\
17 \\
7\end{array}$ & $\begin{array}{l}1 \\
5 \\
5 \\
7\end{array}$ & $\begin{array}{r}1 \\
6 \\
11 \\
6\end{array}$ & $\begin{array}{l}1 \\
2.2 \\
1.6 \\
4.8\end{array}$ & $\begin{array}{l}1 \\
2.3 \\
3.3 \\
1.3\end{array}$ \\
\hline
\end{tabular}

\section{PLATE I}

1. - Transfer of 5 artificial eggs on day 3. Examination on day 7 of pregnancy. Arrow shows swollen areas. The right horn is the control (CT).

2. - Tronsfer on day 3. Cross-section of a recipient uterine horn examined on day 7 of pregnancy. Note decidua cell reaction (CD) in the antimesometrial region. $\times 40$.

3. - Transfer on day 6. Examination on day 7 of pregnancy.

Artificial egg ( $f e$ ) is situated in an uterine chamber without epithelium. $\times 44$.

4. - Transfer of artificial eggs on day 3. Examination on day 7 of pseudopregnancy.

Decidual cells in the antimesometrial region of a swelling. $\times 1260$. 
PLATE I
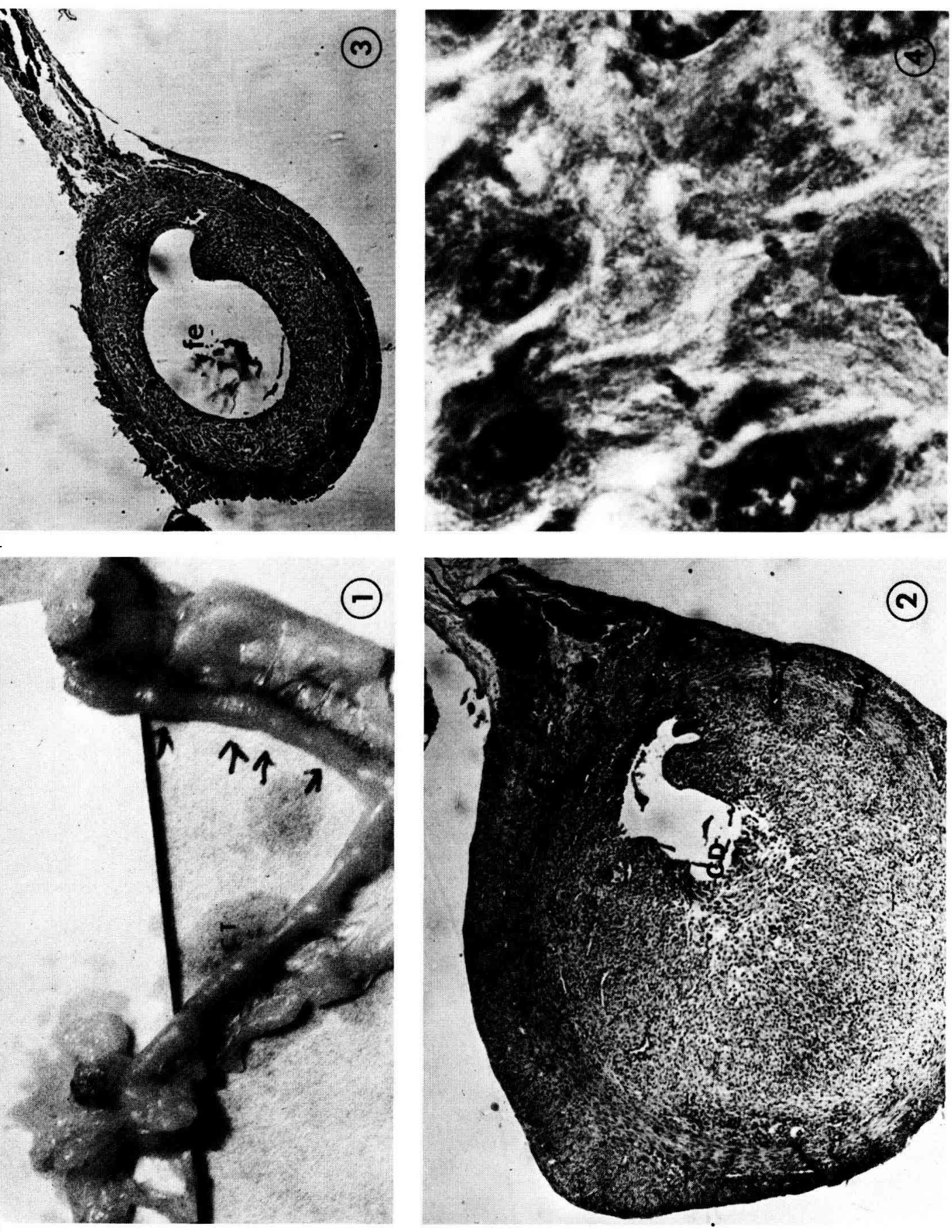
presented swellings (5 out of 11 rats). After transfer on day 6, almost all the rats retained artificial ova, and more than one-half exhibited swellings.

After transfer on day 2 into pseudopregnant recipients, one out of 5 had artificial eggs and a swelling. After transfer on day 3, one-half of the rats showed swellings (6 out of 10) and artificial eggs (5 out of 10). After transfer on day 6, all recipients (7) retained the artificial ova and most of them presented swellings (6 out of 7 rats). The mean number of artificial eggs recovered on day 7 in all pregnant or pseudopregnant rats, including those which lost artificial ova, increased from 0.05 after transfer on day 3 to 3.85 after transfer on day 6 in pregnant rats, and from 0.2 on day 2 to 4.8 on day 6 in pseudopregnant animals. Whatever the number of artificial ova transferred on day 6 into the sterile horn of the pregnant females (table 3), the proportion of subjects retaining artificial eggs or the proportion of eggs remaining fluctuated little.

TABLE 3

Number of artificial eggs and swellings recovered on day 7 of pregnancy when 1 to 15 artificial eggs are transferred on day 6

\begin{tabular}{lrcr}
\hline & \multicolumn{3}{c}{ Number of pregnant rats } \\
\cline { 2 - 4 } & observed & with artificial ova & with swellings \\
\hline & & & 0 \\
1 ova transferred........ & 11 & 7 & 1 \\
2 ova transferred....... & 7 & 20 & 12 \\
5 ova transferred....... & 2 & 11 & 7 \\
6-15 ova transferred..... & 14 & & \\
\hline
\end{tabular}

A significant statistical difference is noted in the mean position of fertilized and artificial ova along the uterus in pregnant and in pseudopregnant rats whatever the day of transfer, and in pregnant females whatever the number of artificial eggs transferred. Contrary to blastocysts these eggs were never more numerous in the middle of the horn, and they frequently gathered in masses, especially after transfer on day 6. There is no significant difference in the mean positions of artificial ova transferred on day 4 and day 6 in pregnant rats or in pseudopregnant rats. We may thus conclude that ova distribution along the horns occurred or continued between day 6 and 7 . In addition, mean artificial egg position in pseudopregnant recipients is significantly different from that in pregnant ones for synchronic transfer (day 4 or 6 ). These results suggest that the presence of blastocysts in one horn affects the distribution of artificial eggs along the other.

Seventy-three swellings were detected in the sterile horns of pregnant females in only 30 out of the 91 operated rats ; 16 of these developed around artificial eggs. The swellings were biggest $(2.28 \mathrm{~mm})$ after transfer on day 3 and most numerous (3.6) after transfer on day 4 . The transfer of one artificial ovum on day 6 did not induce swelling ; the transfer of two or more did. The highest number of swellings was induced by 5 or more artificial ova. Histological study showed no blastocyst in the swelling because migration from the pregnant horn to the other was excluded. After transfer on day 3 , 
the onset of decidual cell reaction was visible in the antimesometrial region of the swellings (Plate I, fig. 2). After transfer on day 6, only some stromal cells were seen dividing in the antimesometrial pole. However, the artificial ovum was then situated in a chamber of the antimesometrial lumen (Plate I, fig. 3), which had already lost its epithelium. Leucocytes were present in many uterine lumina of the swellings.

In pseusopregnant rats, swellings were observed only in the recipient horn and never in the other, except once in the cervix. These swellings were most frequent after transfer on day 4 and were nearly the size $(2.5 \mathrm{~mm})$ of normal swellings $(2.7 \mathrm{~mm})$ after transfer on day 3. Histological observation showed dedicual cells in the antimesometrial stroma (Plate I, fig. 4). If transfer occurred on day 6 , the swellings were smaller $(2.0 \mathrm{~mm}$ ) on day 7 and stromal cell division was uncommom ; on day 9 they had developed $(3.21 \mathrm{~mm})$ and exhibited typical deciduomata.

\section{Discussion.}

Rat blastocysts reach the horns between 3.5 and 4.5 days post-coitum (Sartor, 1969). Our experiments show that before this period, the usually unoccupied horns reject artificial eggs. These results suggest that although spontaneous myometrial contractions are less strong than at estrus (Reynolds, 1949), they are able to expulse the artificial ova in spite of increased progesterone and $20 \propto \mathrm{OH}-\mathrm{P}$ levels on day 2 post-coitum (Alloiteau and Mayer, 1967 ; Hashimoto et al., 1968 ; Yoshinaga, 1973). This expulsion, which occurs in pregnant and pseudopregnant recipients, is then nof due to the ligature of the utero-tubal junction. It also occurs whatever the time lag between transfer and examination. In complementary experiments, we noticed that even a longer time interval does not permit their complete expulsion when they are transferred on day 4 and detected on day 9.

After day 4, only weak contractions are recorded (Reynolds, 1949) which may be considered as responsible for the distribution of fertilized eggs (Böving, 1971 ; Wimsatt, 1975) and probably of artificial eggs. The latter are irregularly distributed and expulsed slowly and continuously. The blastocysts are more regularly distributed and not expulsed. These differences are only due to the dissimilar nature of the eggs ; the artificial ova are made of resin and stained with a substance which might be toxic and thus expulsed.

The artificial eggs may induce decidualization on the antimesometrial side in pregnant and pseudopregnant recipient uterus. Consequently, decidualization is not specifically a response of maternal tissues to the fertilized ova. Uterine ability to elicit a deciduomata is maximum on day 5 post-coitum and is due to estrogen priming, the presence of progesterone for at least 2 days, and the luteal estrogen peak (Yochim and De Feo, 1963 ; De Feo, 1967 ; Clark, 1971 ; Martin et al., 1973 ; Finn and Porter, 1975 ), the decidua growing until day 10 before disappearing (De Feo, 1967). When rats are treated with progesterone alone, only a strong inducer such as PGF $2 \alpha$ or a mechanical stimulation can initiate decidualization (Wiest, 1969, Sananes et al., 1976 ; Mayer et al., 1959). Consequently the luteal estrogen peak does not seem necessary to decidualization induction, but it is reported (Psychoyos and Alloiteau, 1962 ; Martel and Psychoyos, 1976) that this peak is necessary to the implantation of fertilized ova $12 \mathrm{hrs}$ 
later on day 5 post-coitum. If implantation on day 5 is prevented beyond this time lag, the mature blastocysts do not implant and induce the deciduomata process (Psychoyos, 1969 ; Mester et al., 1974). However, our results show that the uterus retains the ability to decidualize during day 6 . It is suggested that this potentiality is retained even to day 9 (Mayer, 1960). The absence of uterine epithelium around the artificial ova may indicate the involvement of the uterus in the destruction of this epithelium. A similar result in pregnant mice (Nilsson, 1977) indicates that resin beads in a sterile horn or blastocysts in a fertile one at early trophoblast invasion locally stimulate the epithelium to produce a proteolytically active secretion.

Our experiments confirm the intervention of the blastocysts in the development of the decidua, which are smaller if induced by artificial ova. Similar results obtained by Alden and Smith (1959) suggest that the trophoblast is responsible for the complete development of decidua ; the artificial eggs are only able to initiate this development. It is reported elsewhere that the blastocysts accelerate the development of decidua (Finn and Porter, 1975).

Reçu en juin 1977.

Accepté en septembre 1977.

Acknowledgments. - I am grateful to Professor C. Thibault for his invaluable help.

Résumé. Les rôles de la mère et des embryons dans la distribution des cufs le long des cornes utérines et dans la décidualisation est étudiée chez les rattes en substituant aux blastocystes des faux embryons de résine. Ces faux embryons sont introduits à l'apex des cornes utérines de femelles « cycliques » ou entre le $2^{\mathrm{e}}$ et le $6^{\mathrm{e}}$ jour post-coïtum chez les femelles pseudogestantes, ou dans les cornes stériles de rattes gestantes. Les faux embryons sont localisés $24 \mathrm{~h}$ après leur introduction chez les femelles cycliques et au $7^{e}$ jour post-coïtum chez les autres. L'étude histologique est effectuée quand la corne présente des renflements. Les faux embryons sont généralement expulsés s'ils ont été introduits avant le $4^{\mathrm{e}}$ jour, date à laquelle les blastocystes arrivent normalement dans les cornes témoins. Après cette date, l'utérus retient des faux embryons : ils sont irrégulièrement répartis le long des cornes utérines et ils induisent des déciduomes plus petits que ne le font les blastocystes. La réaction déciduale est encore induite par les faux embryons introduits le $6^{\mathrm{e}}$ jour. Il semble donc que les blastocystes jouent une part active dans les processus de répartition et d'implantation.

\section{References}

ALDEN R. H., SMITH M. J., 1959. Implantation of the rat egg. J. Exp. Zool., 142, 215-225.

ALLOITEAU J. J., MAYER G., 1967. Problèmes concernant la formation, le maintien et la régression des corps jaunes chez le rat, 189-257. In JOST A., La physiologie de la reproduction chez les mammifères. C.N.R.S., Paris.

BÖVING B. G., 1971. Biomechanics of implantation, 423-442. In BLANDAU R. J., The biology of the blastocyst. Univ. Chicago Press, Chicago.

CLARK B. F., 1971. The effects of estrogen and progesterone on uterine cell division and epithelial morphology in spayed, adrenalectomized rats. J. Endocr., 50, 527-528.

DE FEO V. J., 1967. Decidualization, 191-249. In WYNN R. M., Cellular biology of the uterus. Appleton-Century-Crots, New York.

FINN C. A., PORTER D. G., 1975. The endometrium, 17-104. In FINN C. A., PORTER D. G., The uferus. Elek Sciences, London. 
HASHIMOTO I., HENRICKS D. M., ANDERSON L. L., MELAMPY R. M., 1968. Progesterone and Pregn-4-en-20-ol-3-one in ovarian venous blood during various reproductive states in the rat. Endocrinology, 82, 333-341.

MCLAREN A., 1968. Can beads stimulate a decidual response in the mouse uterus ? J. Reprod. Fert., 15, 313-315.

MARKEE J. E., 1944. Intrauterine distribution of ova in rabbit, Anat. Rec., 88, 329-336.

MARTEL D., PSYCHOYOS A., 1976. Endometrial content of nuclear estrogen receptor and receptivity for ovoimplantation in the rat. Endocrinology, 99, 470-475.

MARTIN L., FINN C. A., TRINDER G., 1973. Hypertrophy and hyperplasia in the mouse uterus after œstrogen treatment : an autoradiographic study. J. Endocr., 56, 133-144.

MAYER G., 1960. Morphologie et physiologie de l'ovoimplantation, 1-32. In FERIN J., GAUDEFROY M., FANARD A., WILKIN P., Les fonctions de nidation uterines et leur troubles. Masson, Paris.

MAYER G., THEVONOT-DULUC A. J., MEUNIER J. M., 1959. Déciduomes et ovoimplantations chez la ratte. Les blastocystes ne s'implantent-ils pas au cours de la phase de vie latente parce que l'endomètre utérin ne peut se décidualiser ? C. R. Soc. Biol., 153, 602-604.

MESTER J., MARTEL D., PSYCHOYOS A., BAULIEU E. E., 1974. Hormonal control of œsirogen receptor in uterus and receptivity for ovoimplantation in the rat. Nature, 250, 776-777.

NILSSON O., 1977. Local secretory response by the mouse uterine epithelium to the presence of a blastocyst or a blastocyst-like bead. Anat. Embryol., 150, 313-318.

PSYCHOYOS A., 1969. Hormonal control of the implantation of embryos, 1-2. In EDWARDS R. G., Research in reproduction, vol, 1, I.P.P.F. London.

PSYCHOYOS A., ALLOITEAU J. J., 1962. Technique de castration chez le rat. C. R. Soc. Biol., 156, 46-49.

REBER A., 1972. Contribution à l'éfude de la nidation chez la rafte. Thèse Doct. $3^{\mathrm{e}}$ cycle, Biol. Anim., Univ. Rouen.

REYNOLDS S. R. M., 1949. Patterns and functions of uterine motility, 3-71. In REYNOLDS S. R. M., Physiology of the uterus, 2nd ed., Harper and brothers, New York.

SANANES N., BAULIEU E. E., LE GOASCOGNE C., 1976. Prostaglandin (s) as inductive factor of decidualization in the rat uterus. Mol. cell. Endocr., 6, 153-157.

SARTOR P., 1969. Chronologie de l'arrivée des cufs fécondés dans les cornes utérines au cours de la progestation chez la ratte. C. R. Soc. Biol., 163, 654-656.

SHELESNYAK M. C., 1957. Some experimental studies on the mechanism of ova-implantation in the rat. Recent Progr. Horm. Res., 13, 269-322.

WIEST W. G., 1969. Progesterone interactions in the rat uterus, 56-78. In WOSTHENHOLME G. E. W., KNIGHT J., Progesterone : its regulafory effect on the myometrium. J and A. Churchill, London.

WIMSATT W. A., 1975. Some comparative aspects of implantation. Biol. Reprod., 12, 1-40.

WITSCHI E., 1962. Development : rat, 304. In ALTMAN P. L., DITTMER D. S., Biological Handbook: Growth including reproduction and morphological development. Fed. Amer. Soc. exper. Biol., Washington.

YOCHIM J. M., DE FEO V. J., 1963. Hormonal control of the onset, magnitude and duration of the uterine sensitivity in the rat by steroid hormones of the ovary. Endocrinology, 72, 317-326.

YOSHINAGA K., 1973. Gonadotrophin - induced hormone secretion and structural changes in the ovary during the nonpregnant reproductive cycle, 363-388. In GREEP R. O., Handbook of physiology, Vol. 2, Amer. physiol. Soc. Washington. 